Ferrata Storti Foundation

\title{
Efficacy of central nervous system prophylaxis with stand-alone intrathecal chemotherapy in diffuse large B-cell lymphoma patients treated with anthracycline-based chemotherapy in the rituximab era: a systematic review
}

Haematologica 2020

Volume 105(7):1914-1924

\section{Correspondence:}

TOBY A. EYRE

toby.eyre@ouh.nhs.uk

Received: June 20, 2019.

Accepted: September 2, 2019.

Pre-published: September 5, 2019.

doi:10.3324/haematol.2019.229948

Check the online version for the most updated information on this article, online supplements, and information on authorship \& disclosures: www. haematologica.org/content/105/7/1914

\section{(C)2020 Ferrata Storti Foundation}

Material published in Haematologica is covered by copyright. All rights are reserved to the Ferrata Storti Foundation. Use of published material is allowed under the following terms and conditions:

https://creativecommons.org/licenses/by-nc/4.0/legalcode. Copies of published material are allowed for personal or internal use. Sharing published material for non-commercial purposes is subject to the following conditions:

https://creativecommons.org/licenses/by-nc/4.0/legalcode, sect. 3. Reproducing and sharing published material for commercial purposes is not allowed without permission in writing from the publisher.

\section{Toby A. Eyre, ${ }^{1}$ Faouzi Djebbari, ${ }^{2}$ Amy A. Kirkwood ${ }^{3}$ and Graham P. Collins ${ }^{1}$}

${ }^{1}$ Department of Clinical Haematology, Oxford University Hospitals NHS Foundation Trust, Oxford; ${ }^{2}$ Department of Pharmacy, Oxford University Hospitals NHS Foundation Trust, Oxford and ${ }^{3}$ Cancer Research UK \& UCL Cancer Trials Centre, UCL Cancer Institute, London, UK

\section{ABSTRACT}

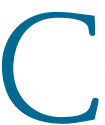
entral nervous system (CNS) relapse of diffuse large B-cell lymphoma remains uncommon but catastrophic. The benefit of standalone intrathecal prophylaxis in reducing CNS recurrence is unclear and remains controversial. No systematic review analysing the evidence for stand-alone intrathecal prophylaxis has been performed in the era of antiCD20 monoclonal antibody therapy. A comprehensive search (01/200201/2019) was systematically performed using Ovid MEDLINE ${ }^{\circledR}$, Ovid EMBASE $^{\circledR}$ and Cochrane. Studies were selected from a total of 804, screened based on predefined inclusion/exclusion criteria, and were critically appraised. Three post hoc analyses (RICOVER-60, RCHOP-14/21, GOYA), one prospective database and 10 retrospective series were included. 7,357 rituximab/obinutuzumab-exposed patients were analysed. The median percentage receiving intrathecal prophylaxis was $11.9 \%$. Cumulative CNS relapse incidence ranged from $1.9 \%$ at 6.5 years to $8.4 \%$ at 5 years. Median time (of medians) to CNS relapse was 10 months. $73 \%$ developed isolated CNS relapses, $24 \%$ concurrent CNS/systemic relapse, and $3 \%$ post-systemic relapse. Reported CNS relapse sites were: parenchymal (58\%), leptomeningeal (27\%), and both (12\%). Event rates were low resulting in limited power within each study to provide robust univariable/multivariable analysis. Intrathecal prophylaxis was not a univariable or multivariable factor associated with a reduction in CNS relapse in any study. We found no strong evidence for the benefit, or indeed genuine lack of benefit, of stand-alone intrathecal prophylaxis in preventing CNS relapse in diffuse large B-cell lymphoma-treated patients using anthracycline-based immunochemotherapy. Current published study designs limit the strength of such conclusions.

\section{Introduction}

Relapse of diffuse large B-cell lymphoma (DLBCL) within the central nervous system (CNS) following front line anthracycline-based immunochemotherapy is relatively uncommon (typically 2-5\%). ${ }^{1-4}$ It typically occurs within the first year of follow up post-treatment and has devastating consequences. The median overall survival following recurrence within the CNS is approximately 2-5 months ${ }^{5,6}$ with few patients achieving long term survival. As a result, attempts over many years have been made to reduce the risk of this complication of DLBCL. Although risk factors ${ }^{1,4}$ for CNS relapse have been clearly described over recent years and the CNS international prognostic index (CNS-IPI) has been established and validated, the optimal and widely applicable CNS prophylactic strategy remains somewhat controversial.

High dose, systemic anti-metabolite therapy, typically in the form of high dose methotrexate (HDMTX), is the most commonly employed systemic prophylactic 
therapy. The evidence base for the efficacy of HDMTX in the rituximab era is relatively weak but has been demonstrated in retrospective single or multicentre series. ${ }^{7-9}$ No randomised prospective studies have been performed. HDMTX is given either following ${ }^{10}$ or in an intercalated fashion alongside rituximab-based immunochemotherapy? HDMTX prophylaxis is widely administered for this purpose; however its toxicity profile typically limits its use to patients under 70 years of age, without serous effusions and with adequate renal function.

Intrathecal (IT) anti-metabolites, typically methotrexate (MTX) and/or cytarabine (ara-c), have also been employed either as stand-alone therapy in patients deemed at high risk of CNS relapse, or as adjunctive therapy to high dose intravenous anti-metabolites. The theoretical basis for IT prophylaxis has historically been extrapolated from the management of other lymphoid cancers such as Burkitt lymphoma ${ }^{11}$ and acute lymphoblastic leukemia. ${ }^{12}$ Although not a universally applied practice, many centres continue to employ stand-alone IT prophylaxis in DLBCL patients at higher risk of CNS relapse who are otherwise being treated with curative intent but who are considered unsuitable candidates for HDMTX due to, for example, age, inadequate renal function, or patient/physician preference. Historical studies have demonstrated that IT methotrexate does not achieve therapeutic concentrations within the brain parenchyma ${ }^{13}$ and IT chemotherapy administration has the potential for well described morbidity ${ }^{14}$ as well as resource and administrative burden.

Although it is clear that rituximab reduces systemic relapse and improves survival in DLBCL, ${ }^{15}$ summarised data within a systematic review published in 2015 are conflicting as to whether rituximab reduces CNS relapse. ${ }^{5}$ There is some evidence that leptomeningeal recurrence may have become less common since the introduction of rituximab, with the majority of CNS relapses being parenchymal in origin. ${ }^{10-12}$ There are few data suggesting that IT prophylaxis may reduce CNS relapse, although this is based on relatively small single or multicentre retrospective studies in heterogenous cohorts primarily from the pre-rituximab era. ${ }^{19,20}$

To date, there is no international consensus regarding which patients should receive stand-alone IT prophylaxis alongside rituximab and anthracycline-based frontline immunochemotherapy and no systematic reviews have been specifically performed to help answer this important question. An initial scoping review found a relatively small number of publications directly related to this question, and as such a comprehensive systematic review was deemed necessary. The purpose of this systematic review was, therefore, to identify evidence of effectiveness of standalone IT prophylaxis in patients treated in the front-line setting for DLBCL with anthracycline-based curative chemotherapy in the anti-CD20 monoclonal antibody era. Our systematic review was not designed to assess the relative value of combined IT and high dose intravenous antimetabolite prophylaxis or high dose intravenous antimetabolite prophylaxis alone as strategies to reduce CNS relapse risk.

\section{Method}

\section{Search strategy}

The review was conducted systematically in accordance with the Preferred Reporting Items for Systematic Review and Meta-
Analysis Protocols (PRISMA-P) guidelines ${ }^{21,22}$ and was registered on the PROSPERO database (CRD42019121174). A comprehensive search was conducted following a systematic search strategy using the electronic databases: Ovid MEDLINE ${ }^{\circledR}$, Ovid EMBASE ${ }^{\circledR}$ and Cochrane Central Register of Controlled Trials. Boolean operators 'AND' and 'OR' were employed, as well as truncation $\left(^{*}\right)$.

Searches included the title and abstract where possible and were restricted to English language only. The search strategy was date restricted from 2002 until January 2019 as the pivotal trial establishing the benefit of rituximab in combination with CHOP was published in January of the year $2002 .{ }^{15}$ Search strategy comprised three main components, using relevant Medical Subject Headings (MESH) terms where possible. Disease component(s) were searched for using the following search terms: diffuse large B-cell lymphoma, DLBCL, central nervous system relapse, CNS relapse, central nervous system recurrence, CNS recurrence, central nervous system progression, CNS progression. Prior therapies component(s) were searched for using the following search terms: rituximab, doxorubicin, anthracycline, R-CHOP, EPOCH and R-CHOEP. Intervention component(s) were searched for using the following search terms: central nervous system prophylaxis, CNS prophylaxis, intrathecal, intrathecal prophylaxis, intrathecal chemotherapy, intrathecal methotrexate, intrathecal cytarabine.

Full search strategies are summarised in the Online Supplementary Tables S1-3. The search was expanded using retrospective snowballing from the reference lists of initial studies included to ensure a sensitive and comprehensive search.

\section{Screening search results}

Search results were independently double-screened by the research team both at abstract and full text screening stages using eligibility criteria displayed in Table 1. Disagreements between any two researchers were referred to a third researcher to reach a consensus.

\section{Quality appraisal and data extraction}

Standardised Critical Appraisal Skills Programme (CASP) tools (https://casp-uk.net/casp-tools-checklists) were utilised to appraise the quality of study design, methodology and data reporting. CASP tools used were specific to each study type reviewed (e.g. clinical trial, cohort study). Studies were assigned a quality rating score as follows: 5 (high), 4 (moderate to high), 3 (moderate), 2 (moderate to low), or 1 (low). Limitations identified from reported data in individual studies were reported including low quality rating papers, which were also transparently reported in the review.

\section{Data extraction and analysis}

Extracted data were reviewed by all the research team (FD, TAE, GPC) and tabulated to summarise key findings. Key data extracted from each study were: author and year of publication, design, sample characteristics (type of rituximab-containing immunochemotherapy, key inclusion criteria), and reported outcomes (cumulative incidence of CNS relapse, site of CNS relapse, concurrence of systemic relapse and a documented analysis of the effectiveness of IT prophylaxis in preventing CNS relapse). For studies including patients treated both with and without rituximab, presented data for rituximab-exposed patients where available (superscript ' $R$ ', Table 2). The research design(s) and study characteristics, clarity of reporting, and statistical significance of reported data were assessed to determine the strengths and limitations of the evidence. All included studies underwent full statistical analysis (AAK). 
Table 1. Key eligibility criteria.

\section{Inclusion}

-Studies of DLBCL as the dominant lymphoma subtype assessing the risk of CNS relapse

-Studies of DLBCL in the rituximab era: rituximab or obinutuzumab exposed patients represented $\geq 100$ patients and the majority of the patients within the individual study.

-Studies of DLBCL treated with anthracycline-based chemotherapy

-Studies analysing the relative influence of stand-alone IT prophylaxis on outcome

-Meta-analysis

- Late phase clinical trials

- Cohort studies

- Cross-sectional studies

- Retrospective studies

-Observational studies

-Case-control studies

\section{Exclusion}

- Case series with $<100$ patients treated with rituximab-

chemotherapy

- CNS involvement at diagnosis

-Non-rituximab or non-obinutuzumab exposed cohorts

- Cohorts where no patients received CNS prophylaxis

-Early phase clinical trials

-Pharmacokinetic studies

- Narrative reviews

-Opinion papers

-Education papers

-Commentaries

-Editorials

- Conference abstracts

- Case-reports

-Animal studies

DLBCL: diffuse large B cell lymphoma; CNS: central nervous system; IT: intrathecal.

\section{Results}

\section{Search results}

Of 804 search results, 12 studies were eligible for inclusion. One study was later excluded because of the authors concerns over quality of the reported study. ${ }^{23}$ Following the search expansion phase, three additional studies were included. ${ }^{6,24,25}$ In total, 14 studies met eligibility criteria for this review. Full details of the PRISMA inclusion/exclusion process are presented in Figure 1. Three studies were post hoc analyses from prospective randomised controlled clinical trials, one was an analysis of a multicentre, national, prospective database and all others were retrospective data series (seven single centre; three multicentre). Three studies were conducted in Japan, two in the USA and Canada, and one each in Germany, the UK, China, Singapore, South Korea and Thailand respectively.

A cumulative total of 7,357 (74.7\%) anti-CD20 monoclonal antibody-exposed patients were assessed across the 14 series which included a cumulative total of 9,842 patients overall. All studies used rituximab or obinutuzumab ${ }^{24}$ plus CHOP (cyclophosphamide, doxorubicin, vincristine and prednisolone) or CHOP-like regimens as the chemotherapy backbone given at between 14-28 day intervals apart from a single study which analysed a cohort treated with DA-EPOCH (dose adjusted etoposide, prednisolone, vincristine, cyclophosphamide and doxorubicin). ${ }^{26}$ Five studies included patients $\geq 18$ years, two studies included patients $\geq 16$ years, one study included patients $\geq 15$ years and one included patients $60-80$ years. Five studies did not define age criteria. Three studies included patients with transformed indolent B-cell nonHodgkin lymphoma (iNHL), and four studies included a relatively small number of patients with primary mediastinal B-cell lymphoma (PMBCL). The median percentage of patients receiving some form of IT prophylaxis across each individual study was $11.9 \%$ (range: $4.0-38.9 \%$ ). The dosing frequency, total number of IT injections administered and chemotherapy agent used varied (Table 2). The
IT chemotherapy agent was not defined in all studies, although methotrexate and ara-C were the only employed agents used when described.

\section{CNS relapse outcomes}

The cumulative incidence rate of CNS relapse was reported in 10 studies and a crude rate of CNS relapse (number of CNS events/total number of patients) was reported in four studies. The cumulative incidence CNS relapse rate from eight studies reporting rates in antiCD20 monoclonal antibody-specific cohorts ranged between $1.9 \%$ at a median of 6.5 years follow-up ${ }^{27}$ and $8.4 \%$ at 5 years. ${ }^{28}$ Across the nine studies specifically reporting a median time to CNS relapse in anti-CD20 monoclonal antibody-exposed (sub)populations, the median of those median times reported was 10 months.

In 10 studies reporting details regarding the nature of the CNS relapses in rituximab or obinutuzumab exposed patients, there were $73 \%$ (128 of 175) isolated CNS relapses, $24 \%$ (42 of 175) CNS relapses concurrent at the time of systemic relapse, and 3\% (5 of 175) cases of CNS relapse occurring at a later time point following documented systemic relapse.

Ten studies provided a detailed breakdown of the anatomical site of CNS relapse in rituximab or obinutuzumab-exposed patients. In total there were 191 CNS relapses, of which 111 (58\%) were parenchymal, 52 (27\%) were leptomeningeal, 23 (12\%) were both parenchymal and leptomeningeal, one was intraocular $(1 \%)$ and four $(2 \%)$ were either not known or not specifically defined. Therefore, a total of $70 \%$ (134 of 191) of patients had demonstrable parenchymal involvement at CNS relapse.

\section{Intrathecal prophylaxis efficacy}

Efficacy analyses were performed in all 14 studies and these are presented Tables $3 \mathrm{~A}-\mathrm{C}$. Patients receiving IT prophylaxis typically had demonstrable risk factors for CNS relapse, although the recommendations for IT prophylaxis varied considerably across studies (Table 4). As such, these 


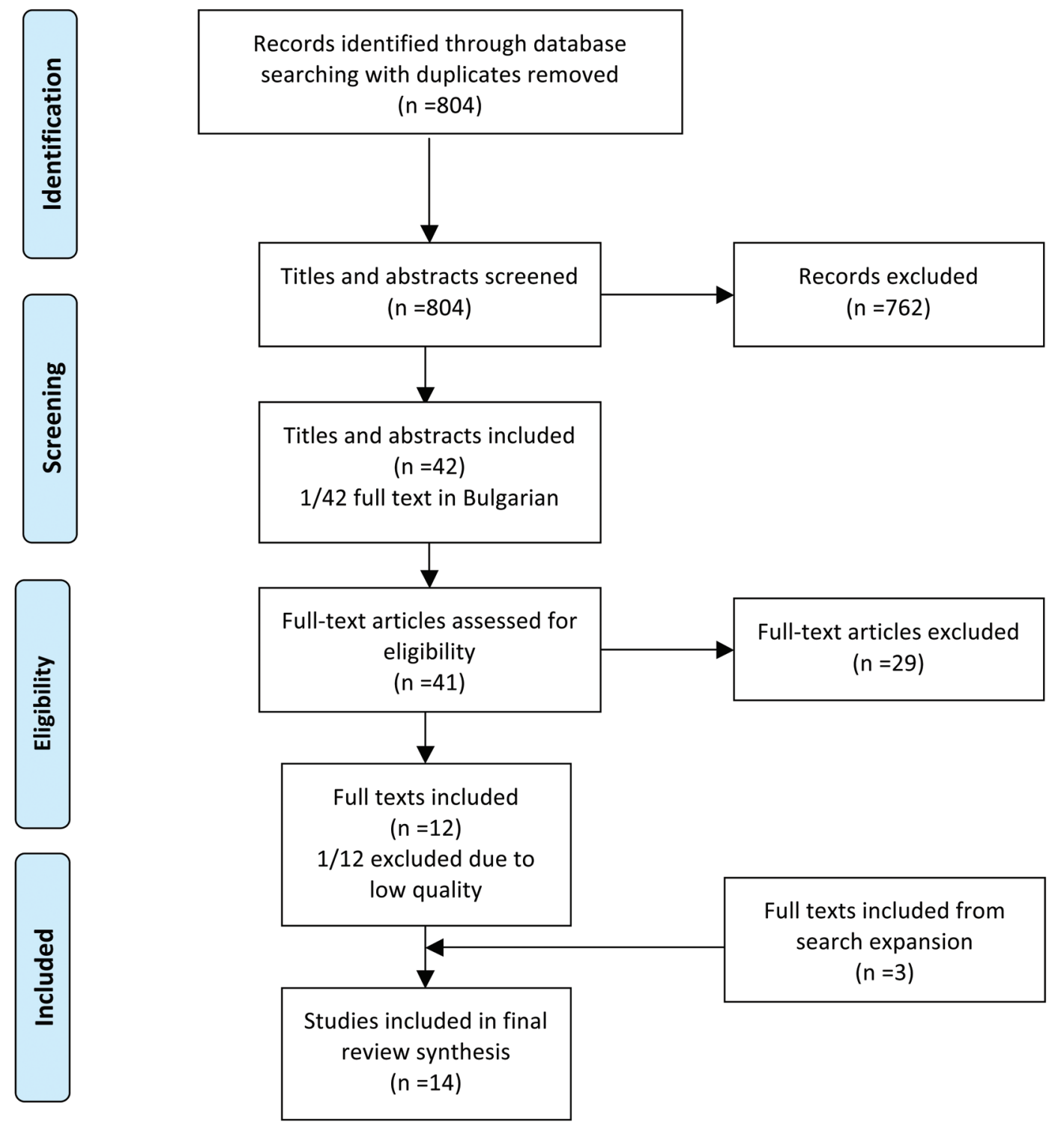

Figure 1. PRISMA Flow diagram of search strategy and inclusion/exclusion.

patients often were at higher risk of relapse than patients not receiving IT prophylaxis. Univariable analysis was performed in all studies and no study demonstrated clear evidence of a reduction in the risk of CNS relapse when IT prophylaxis was used. Multivariable analyses were performed and described in nine studies (Tables 3A-C). IT prophylaxis was not found to be a univariable or multivariable factor associated with a statistically significant reduction in the risk of CNS relapse in any of the studies examined.

No adjusted analyses were described in one study. ${ }^{28}$ Adjusted analyses were reported in the remaining four studies in a variety of forms 1 . Adjustment for CNS-IPI $(n=2) ; 24,272$. Propensity matching to analyse survival (progression-free and overall survival) but not CNS relapse $(\mathrm{n}=1) ;{ }^{29} 3$. Proportional hazard ratio to assess interaction between rituximab and IT prophylaxis with a univariable/multivariable analysis looking at clinical risk factors associated with CNS relapse and not IT prophylaxis $(n=1) .{ }^{30}$ None of these adjusted analyses showed that IT prophylaxis provided any benefit in reducing the risk of CNS relapse in the anti-CD20 antibody era.

Of note, no individual analysis reported the morbidity associated with IT prophylaxis in terms of the risk of adverse events, for example, risk of systemic infection, post lumbar puncture headache or dural leak.

\section{Quality and statistical appraisal}

We identified a range of study types including post hoc analyses of randomised clinical trials, prospective and retrospective cohort studies. None of the studies prospectively asked whether CNS IT stand-alone prophylaxis reduces the rate of CNS relapse. Although the absolute number of patients included within each study was relatively large, the absolute event number across studies was low. As a result, the statistical power within each study to provide 
Table 2. Data extraction table.

\begin{tabular}{|c|c|}
\hline Data to be extracted & Item \\
\hline Publication ID & $\begin{array}{l}\text { - Author } \\
\text { - Publication date }\end{array}$ \\
\hline Study aim & - Title/Purpose/Aim \\
\hline Study design & $\begin{array}{l}\text { - Study type and design: meta-analysis, late phase clinical trial, } \\
\text { post hoc analysis of late phase clinical trials, cohort study, cross-sectional study, retrospective } \\
\text { study, observational study, case-control study } \\
\text { - Key study inclusion criteria for cohort studied if specified in manuscript }\end{array}$ \\
\hline Sample characteristics & $\begin{array}{l}\text { - Number of participants } \\
\text { - Years of data collection } \\
\text { - DLBCL subtypes } \\
\text { - Proportion and total number of cohort receiving rituximab-containing } \\
\text { anthracycline-based regimen } \\
\text { - Rituximab or obinutuzumab-containing immunochemotherapy regimen(s) used } \\
\text { for DLBCL treatment } \\
\text { - Proportion of patients (total +/- rituximab or obinutuzumab exposed patients } \\
\text { depending on what is reported) receiving IT prophylaxis } \\
\text { - Type of IT prophylaxis received }\end{array}$ \\
\hline Findings & $\begin{array}{l}\text { - Number of CNS relapses and whether concurrent with systemic relapse or isolated CNS } \\
\text { relapse: either of total population or rituximab population. This will be specified in analysis. } \\
\text { - Cumulative incidence of CNS relapse at time point described in manuscript: either of } \\
\text { total population or rituximab population. This will be specified in analysis. } \\
\text { - Site of CNS relapse: parenchymal, leptomeningeal, both, unknown: either of total } \\
\text { population or rituximab population. This will be specified in analysis. } \\
\text { - Documentation of the analysis of the effectiveness of IT prophylaxis in assessing } \\
\text { the CNS relapse risk. }\end{array}$ \\
\hline Strengths and limitations & $\begin{array}{l}\text { - CASP tool scores and comment on the nature and quality of the statistician analysis } \\
\text { performed }\end{array}$ \\
\hline
\end{tabular}

DLBCL: diffuse large B cell lymphoma; CNS: central nervous system; IT: intrathecal; CASP: Critical Appraisal Skills Programme.

clear, robust univariable and multivariable analysis was limited. A number of studies ${ }^{28,35}$ within the analysis simply report the hazard ratio or absolute percentage relapse rate comparison between patients receiving IT prophylaxis versus those not in receipt of prophylaxis.

The studies included often show that the rate of CNS relapse is increased in patients receiving prophylaxis. This finding primarily relates to the confounding effects of patient selection i.e. those at higher risk of CNS relapse are those who receive prophylaxis, however, no attempt was made to adjust for these risk factors in a number of the studies. As such, it is difficult to formally discern the value of IT prophylaxis from univariable, unadjusted analysis. A negative or null result i.e. hazard ratio $\geq 1$ (or more events in the IT-prophylaxis group) as seen in 8 of 11 studies, or small, non-significant protective effect as seen in 3 of 11 studies does not imply that CNS prophylaxis is harmful or ineffective, but may show that it is simply not enough to overcome the increased baseline risk in the population which were treated.

A single study ${ }^{23}$ was excluded from the analysis because of concerns regarding the integrity of the data and the quality of the analysis performed. A comparison across the 14 studies was also limited by the variable indications for IT prophylaxis and the different histologies and regimens included.
Multivariable analyses could help to reduce the effects of (known) confounding factors but, in this case, there are multiple factors of interest (median 16, range: 11-26) in the 13 papers which quote univariable analysis results) and, given the small number of events (median 20, range: 8-61), all of the cohorts studied would fail the ten-events-perfactor rule ${ }^{36}$ which is generally suggested to ensure the stability of a statistical model.

A number of papers ${ }^{2,17,25,32,34,35,37}$ (Villa et al., Tai et al., Guirguis et al., Tomita et al., Cai et al., Wudhikarn et al. and possibly Song et al.). reduced the number of factors in multivariable analyses by only including those factors with $P>l \geq 0.1$ in the univariable analysis. In some cases this meant CNS IT prophylaxis was not included in multivariable models at all1,25,32 (Villa et al., Guirguis et al., possibly Song et al.), and in others it may have excluded factors which were not significant but did have a confounding effect on the benefit of CNS prophylaxis. Two studies (post hoc analysis of the R-CHOP 14 vs. 21 and GOYA randomised controlled trials) presented results adjusted for the CNS-IPI only ${ }^{27}$ (Gleeson et al.) or within the different CNS-IPI risk levels ${ }^{24}$ (Klanova et al.), neither found any benefit to IT prophylaxis but, as with reduced the models mentioned above, both could also have suffered from the exclusion of confounders. Kumar and colleagues used a propensity score to match patients with and without CNS 
Table 3A. Studies reporting an efficacy analysis of stand-alone intrathecal prophylaxis in front line diffuse large B-cell lymphoma in rituximab era

\begin{tabular}{|c|c|c|c|c|c|c|c|c|c|c|c|}
\hline $\begin{array}{l}\text { Reference: } \\
\text { author, } \\
\text { journal, year }\end{array}$ & $\mathrm{N}$ & $\begin{array}{c}\text { Data set: } \\
\text { type and years }\end{array}$ & $\begin{array}{l}\text { Study } \\
\text { inclusion }\end{array}$ & $\begin{array}{c}\text { 1st line } \\
\text { R-chemotherapy }\end{array}$ & $\begin{array}{c}\text { CNS } \\
\text { Relapse }\end{array}$ & $\begin{array}{l}\text { \% receiving IT } \\
\text { prophylaxis }\end{array}$ & $\begin{array}{c}\text { Median time } \\
\text { to CNS } \\
\text { relapse } \\
\text { (range/ } 95 \% \text { CI } \\
\text { given as available) }\end{array}$ & $\begin{array}{l}\text { Cumulative } \\
\text { incidence of } \\
\text { CNS relapse } \\
\text { (95\% Cl provided } \\
\text { where reported) }\end{array}$ & $\begin{array}{l}\text { Site of CNS } \\
\text { relapse }\end{array}$ & $\begin{array}{l}\text { Evidence } \\
\text { of IT CNS } \\
\text { prophylaxis } \\
\text { effectiveness? }\end{array}$ & $\begin{array}{l}\text { CASP } \\
\text { Score }\end{array}$ \\
\hline
\end{tabular}

\begin{tabular}{|c|c|c|c|c|c|}
\hline Boehme et al., 1217 & Post hoc & $60-80$ years & R-CHOP-14: & Total: 58/22 & $22.4 \%$ \\
\hline Blood & analysis of & with & 608 & Isolated: $34 / 16^{\mathrm{R}}$ & $(273 / 1222)$ \\
\hline \multirow[t]{4}{*}{$2009^{30 * * *}$} & RICOVER-60 & untreated & CHOP-14: & Concurrent: $24 / 6^{R}$ & $\geq 1$ IT MTX. \\
\hline & trial & 'aggressive & $609 . * *$ & & $16.6 \%$ \\
\hline & & B-cell lymphoma'. & & & $(202 / 1222)$ \\
\hline & & $\begin{array}{c}944 \text { (81.6\%) DLBCL } \\
\text { 1\% PMBCL. }\end{array}$ & & & 4 IT MTX \\
\hline
\end{tabular}

$\begin{array}{cccc}\text { All patients: } & \text { 2-year: } & 11^{\mathrm{R}} \text { parenchymal, } & \text { Overall } \\ 8 \text { months } & 4.1 \% & 2^{\mathrm{R}} \text { both; } 9^{\mathrm{R}} & \text { percentage } \\ \text { (range 1-39) } & (95 \% \mathrm{Cl} 2.3-5.9 \%)^{\mathrm{R}} & \text { leptomeningeal } & \text { of CNS events: } \\ & & & \\ & & & \text { IT MTX 2.5\% us. nil } \\ & & 4.4 \% \text {; whole cohort. }\end{array}$

A subgroup analysis of high risk patients adjusted for IPI

found a significant interaction between IT MTX exposure and Rituximab exposure $(\mathrm{RR}=6.1)$, with the risk of CNS relapse significantlyreduced if IT MTX was given in $\mathrm{CHOP}$ group but no difference in R-CHOP group. Effect of rituximab significant regardless of IT MTX.

\begin{tabular}{|c|c|c|c|c|c|c|c|c|c|c|c|}
\hline $\begin{array}{l}\text { Shimazu et al., } \\
\text { Int J of Hematol } \\
2009^{31}\end{array}$ & & $\begin{array}{l}\text { Retrospective } \\
\text { single center; } \\
\text { 1996-2007 }\end{array}$ & $\begin{array}{c}\text { No age limit } \\
\text { defined; } \\
\text { untreated } \\
\text { de novo DLBCL } \\
\text { or transformed } \\
\text { indolent NHL }\end{array}$ & $\begin{array}{c}\text { CHOP/ } \\
\text { CHOP-like: } 165 \\
\text { R-CHOP/ } \\
\text { R-CHOP-like: } 338 \\
\end{array}$ & $\begin{array}{c}\text { Total: } 42 / 22^{\mathrm{R}} \\
\text { Isolated: } 28 / 14^{\mathrm{R}} \\
\text { Concurrent: } 14 / 8^{\mathrm{R}} \\
8\end{array}$ & $\begin{array}{l}4.7 \%(18 / 385) \\
\text { IT prophylaxis }\end{array}$ & 21.5 months $^{\mathrm{R}}$ & $\begin{array}{c}\text { All patients: } \\
\text { 1-year: } 6.5 \% \\
\text { (95\% CI: } 6.0-7.14)\end{array}$ & $\begin{array}{c}32 \\
\text { parenchymal; } \\
10 \\
\text { leptomeningeal } \\
\\
\text { in } \\
(P=\end{array}$ & $\begin{array}{c}\text { Overall \% of CNS } \\
\text { events 1/18 (5.6\%) } \\
\text { IT prophylaxis vs. } 40 / 367 \\
\quad(10.9 \%) \text { for nil. } \\
\text { Use of IT prophylaxis did } \\
\text { not appear significantly } \\
\text { decrease CNS relapse } \\
\text { in logistic regression UVA } \\
=0.478) \text { or MVA }(P=0.571) \text {. }\end{array}$ & 2 \\
\hline $\begin{array}{l}\text { Villa et al. } \\
\text { Ann Oncol } \\
2009^{25 * * *}\end{array}$ & 435 & $\begin{array}{l}\text { Retrospective, } \\
\text { single } \\
\text { center; } \\
\text { 1999-2005 } \\
\\
\text { te }\end{array}$ & $\begin{array}{l}\geq 16 \text { years } \\
\text { with advanced } \\
\text { stage or any } \\
\text { stage DLBCL or } \\
\text { PMBCL with } \\
\text { sticular involveme }\end{array}$ & $\begin{array}{l}\text { CHOP: } 126 \\
\text { R-CHOP: } 309\end{array}$ & 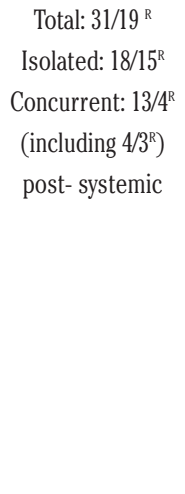 & $\begin{array}{c}4 \%(12) \text { IT } \\
\text { prophylaxis }{ }^{\mathrm{R}} \\
\text { alternating IT } \\
\text { MTX and ara-C }\end{array}$ & 6.7 months $^{\mathrm{R}}$ & 3 -year: $6.4 \%^{\mathrm{R}}$ & $\begin{array}{l}12^{\mathrm{R}} \text { parenchymal; } \\
4^{\mathrm{R}} \text { both; } \\
3^{\mathrm{R}} \text { leptomeningeal } \\
\\
\text { vs. } 1 \\
\text { Use of } \\
\text { to de } \\
(P= \\
\text { inclu }\end{array}$ & $\begin{array}{l}\text { Overall \% of CNS } \\
\text { events: CHOP cohort, } \\
3 / 8(37.5 \%) \\
\text { IT prophylaxis us. } \\
\text { 9/118 (7.6\%) for nil. } \\
\text { R-CHOP cohort, } \\
\text { 0/12 (0\%) IT prophylaxis } \\
\text { 19/297 (6.5\%) (7.6\%) for nil. } \\
\text { f IT prophylaxis did not appear } \\
\text { lecrease CNS relapse on UVA } \\
=0.364, \text { R-CHOP cohort) not } \\
\text { luded in MVA ( } P>0.1 \text { in UVA) }\end{array}$ & r \\
\hline $\begin{array}{l}\text { Tai et al., } \\
\text { Ann Hematol } \\
2011^{2}\end{array}$ & 499 & $\begin{array}{l}\text { Retrospective, } \\
\text { single center; } \\
2000-2008\end{array}$ & $\begin{array}{l}\text { No age limit } \\
\text { defined; } \\
\text { untreated } \\
\text { DLBCL }\end{array}$ & $\begin{array}{c}\text { CHOP: } 179 \\
\text { R-CHOP: } 320\end{array}$ & $\begin{array}{c}\text { Total: } 30 / 20^{R} \\
\text { Isolated: N/R } \\
\text { Concurrent: N/R }\end{array}$ & $\begin{array}{l}\text { 18\% (59/320) } \\
\text { IT prophylaxis }\end{array}$ & $\begin{array}{l}\text { All patients: } \\
6.7 \text { months } \\
\text { (range 1.9-45.2) } \\
\text { 2-year: } 6.0 \% \\
(95 \% \text { Cl: } 3.8-9.4)^{\mathrm{R}}\end{array}$ & R & $\begin{array}{r}\text { (all patie } \\
\text { vs. } 21 \\
\text { prophyla } \\
\text { CNS rela } \\
\text { those receiv } \\
\text { high } \\
\mathrm{MVA} \\
\text { report } \\
\text { was in } \\
\text { Only factor } \\
\text { in MI }\end{array}$ & $\begin{array}{l}\text { Overall } \% \text { of CNS events } \\
\text { ents): } 9 / 82(11.0 \%) \text { IT prophylax } \\
1 / 417(5.0 \%) \text { for nil. Use of IT } \\
\text { laxis did not appear to decreas } \\
\text { lapse on UVA ( } P=0.032 \text {; higher } \\
\text { iving IT prophylaxis, or } P=0.98 \text {, } \\
\text { hrisk only). For all patients, } \\
\text { A non-significant ( } P \text {-value not } \\
\text { rted), unclear if IT prophylaxis } \\
\text { included in R-CHOP only MVA. } \\
\text { rs with } P<0.1 \text { in UVA included } \\
\text { WVA. No IPI-adjusted analysis. }\end{array}$ & $\begin{array}{l}2 \\
\text { seis } \\
\text { in } \\
\text { se }\end{array}$ \\
\hline
\end{tabular}


prophylaxis allowing for a univariable analysis comparing these groups. They also found no difference in CNS relapse risk, but again this would rely on how well matched the groups were and whether this was enough to overcome the issues with confounding.

Analyses, including which factors were or were not included in multivariable analyses, were often poorly described with some papers using inappropriate methods which did not allow for time ${ }^{31}$ (Shimazu et al.) when comparing risk factors, and with a lack of consistency in dealing with competing risks (systemic only relapse or death from other causes). This means the cumulative incidences

Table 3B. Studies reporting an efficacy analysis of stand-alone intrathecal prophylaxis in front line diffuse large B-cell lymphoma in rituximab era

\begin{tabular}{|c|c|c|c|c|c|c|c|c|c|c|c|}
\hline $\begin{array}{l}\text { Reference: } \\
\text { author, } \\
\text { journal, year }\end{array}$ & $\mathbf{N}$ & $\begin{array}{c}\text { Data set: } \\
\text { type and years }\end{array}$ & $\begin{array}{c}\text { Study } \\
\text { inclusion }\end{array}$ & $\begin{array}{c}\text { 1st line } \\
\text { R-chemotherapy }\end{array}$ & $\begin{array}{c}\text { CNS } \\
\text { py } \quad \text { Relapse }\end{array}$ & $\begin{array}{l}\text { \% receiving IT } \\
\text { prophylaxis }\end{array}$ & $\begin{array}{c}\text { Median time } \\
\text { to CNS } \\
\text { relapse } \\
\text { (range/ } 95 \% \text { CI } \\
\text { given as available) }\end{array}$ & $\begin{array}{l}\text { Cumulative } \\
\text { incidence } \\
\text { of CNS } \\
\text { relapse } \\
\text { (95\% CI provided } \\
\text { where reported) }\end{array}$ & $\begin{array}{l}\text { Site of CNS } \\
\text { relapse }\end{array}$ & $\begin{array}{l}\text { Evidence } \\
\text { of IT CNS } \\
\text { prophylaxis } \\
\text { effectiveness? }\end{array}$ & $\begin{array}{l}\text { CASP } \\
\text { Score }\end{array}$ \\
\hline $\begin{array}{l}\text { Guirguis et al. } \\
\text { Br J Haematol } \\
2012^{17}\end{array}$ & 214 & $\begin{array}{l}\text { Retrospective, } \\
\text { single center; } \\
\text { 1999-2005 }\end{array}$ & $\begin{array}{c}\geq 16 \text { years with } \\
\text { DLBCL } \geq 1 \\
\text { cycle of R-CHOP; } \\
\text { including } \\
\text { transformed } \\
\text { indolent NHL }\end{array}$ & $\begin{array}{l}\text { R-CHOP } \\
(100 \%)\end{array}$ & $\begin{array}{c}\text { Total: } 8 \\
\text { Isolated: } 6 \\
\text { Concurrent: } 2 \\
\text { (post systemic) }\end{array}$ & $\begin{array}{l}4.7 \% \text { IT MTX } \\
\text { prophylaxis } \\
\end{array}$ & $\begin{array}{l}17 \text { months } \\
\text { (range 6-35) }\end{array}$ & $\begin{array}{c}\text { Not reported; } \\
\text { Overall rate: } 3.7 \%\end{array}$ & $\begin{array}{l}5 \text { parenchymal; } \\
1 \text { both; } \\
2 \text { leptomeningeal }\end{array}$ & $\begin{array}{c}\text { Use of IT } \\
\text { prophylaxis } \\
\text { did not appear } \\
\text { to decrease CNS } \\
\text { relapse on UVA } \\
P=0.994) . \text { Only factors } \\
\text { with } P<0.1 \text { in UVA } \\
\text { included in MVA. }\end{array}$ & 2 \\
\hline
\end{tabular}

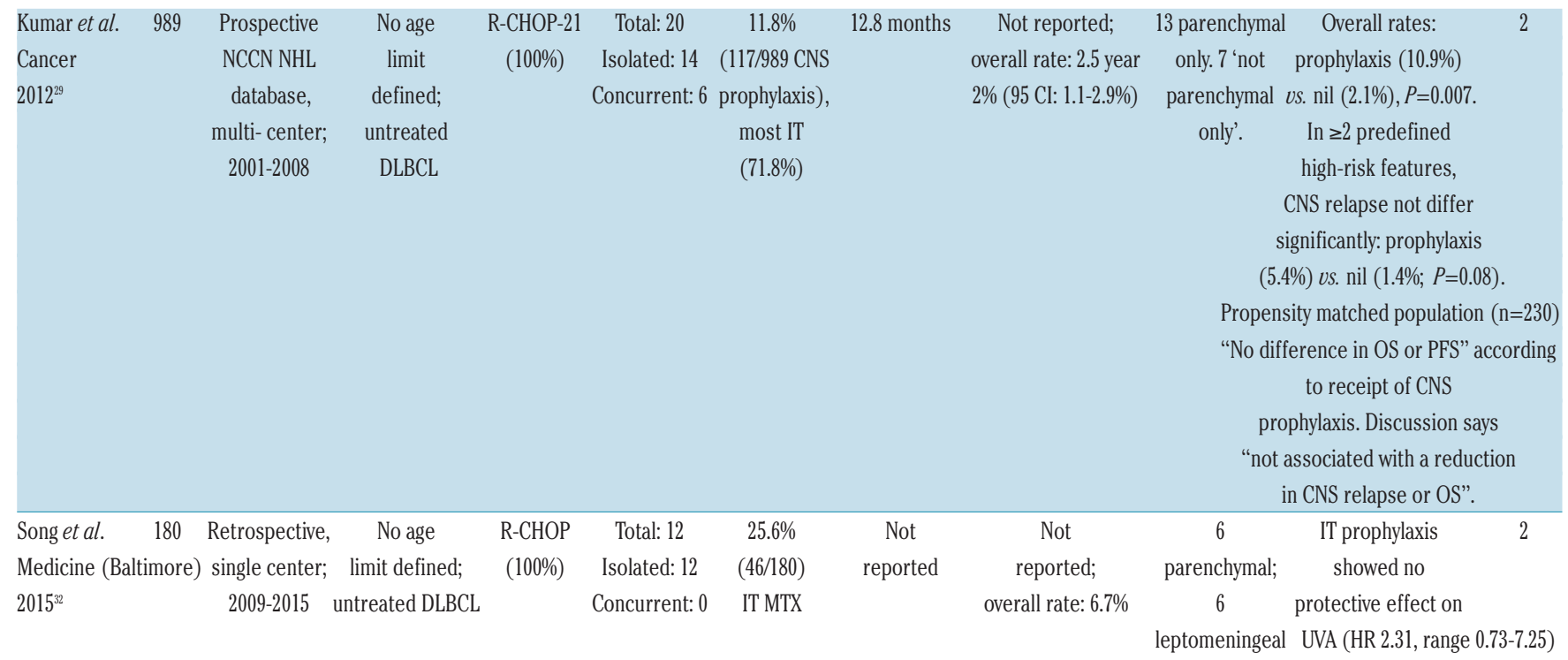

$P=0.15$ : higher in those receiving IT CNS prophylaxis).

Unclear if IT prophylaxis was included

in MVA analyses but not reported

to be significant in MVA.

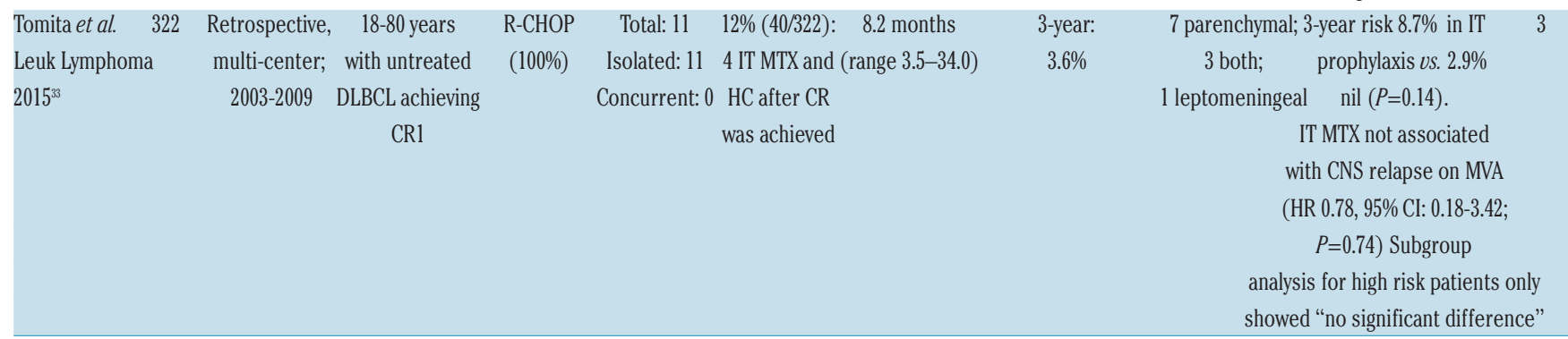

*two patients received high dose methotrexate. ${ }^{* *}$ five CNS involvement at diagnosis excluded. R $=$ in RCHOP subgroup. ${ }^{* * *}$ studies added after initial and post-systematic review scoping. NCCN: National Comprehensive Cancer Network; CNS: central nervous system; R-CHOP: rituximab, cyclophosphamide, doxorubicin, vincristine, prednisolone; RDA-EPOCH: rituximab plus dose adjusted etoposide, prednisolone, vincristine, cyclophosphamide, doxorubicin; O-CHOP: obinutuzumab, cyclophosphamide, doxorubicin, vincristine, prednisolone DLBCL: diffuse large B-cell lymphoma; NHL: nonside, prednisolone, vincristine, cyclophosphamide, doxorubicin; O-CHOP: obinutuzumab, cyclophosphamide, doxorubicin, vincristine, prednisolone DLBCL: diffuse large B-cell lymphoma; NHL: non-
Hodgkin lymphoma;ASCT: autologous stem cell transplantation; HGT: high grade transformation; CLL: chronic lymphocytic leukaemia; FL: follicular lymphoma; GZ: gray zone; CR1: first complete remisHodgkin lymphoma; ASCT: autologous stem cell transplantation; HGT: high grade transformation; CLL: chronic lymphocytic leukaemia; FL: follicular lymphoma; GZ: gray zone; CR1: first complete remis-
sion; PMBCL: primary mediastinal B-cell lymphoma; IPI: international prognostic index; IT: intrathecal; MTX: methotrexate; HD: high dose; ara-C: cytarabine; HC: hydrocortisone; HR: hazard ratio; CI: confidence interval; UVA: univariable analysis; MVA: multivariable; N/R: not reported; IQR: interquartile range; RR: risk ratio; OS: overall survival; PFS: progression-free survival. 
Table 3C. Studies reporting an efficacy analysis of stand-alone intrathecal prophylaxis in front line diffuse large B-cell lymphoma in rituximab era

\begin{tabular}{|c|c|c|c|c|c|c|c|c|c|c|c|}
\hline $\begin{array}{l}\text { Reference: } \\
\text { author, } \\
\text { journal, year }\end{array}$ & N & $\begin{array}{c}\text { Data set: } \\
\text { type and years }\end{array}$ & $\begin{array}{c}\text { Study } \\
\text { inclusion }\end{array}$ & $\begin{array}{c}\text { 1st line } \\
\text { R-chemotherapy }\end{array}$ & $\begin{array}{c}\text { CNS } \\
\text { Relapse }\end{array}$ & $\begin{array}{l}\text { \% receiving } \\
\text { IT prophylaxis }\end{array}$ & $\begin{array}{l}\text { Median time } \\
\text { to CNS } \\
\text { relapse } \\
\text { (range/95\% Cl } \\
\text { given as } \\
\text { avallable) }\end{array}$ & $\begin{array}{l}\text { Cumulative } \\
\text { incidence } \\
\text { of CNS } \\
\text { relapse } \\
\text { (95\% CI provided } \\
\text { where reported) }\end{array}$ & $\begin{array}{c}\text { Site } \\
\text { of CNS } \\
\text { relapse }\end{array}$ & $\begin{array}{l}\text { Evidence } \\
\text { of IT } \\
\text { CNS } \\
\text { prophylaxis } \\
\text { effectiveness? }\end{array}$ & $\begin{array}{l}\text { CASP } \\
\text { Score }\end{array}$ \\
\hline $\begin{array}{l}\text { Cai et al } \\
\text { Chin j Cancer } \\
2016^{34}\end{array}$ & 511 & $\begin{array}{l}\text { Retrospective } \\
\text { single center; } \\
\text { 2003-2012 }\end{array}$ & $\begin{array}{c}\geq 18 \text { years } \\
\text { with newly } \\
\text { diagnosed } \\
\text { DLBCL }\end{array}$ & $\begin{array}{l}\text { CHOP: } 135 \\
\text { R-CHOP: } 376\end{array}$ & $\begin{array}{l}\text { Total: } 25 / 14^{\mathrm{R}} \\
\text { Isolated: N/R } \\
\text { Concurrent: N/R }\end{array}$ & $\begin{array}{c}\text { 11.8\%R } \\
(44 / 373 \\
(3 \text { unknown)): } \\
\text { IT MTX and ara-C } \\
\text { for each cycle } \\
\text { of R-CHOP }\end{array}$ & $\begin{array}{l}6.5 \text { months R } \\
\text { C }\end{array}$ & $\begin{array}{l}\text { 3-year: } 4.9 \% . \\
\text { 3-year: } 2.7 \%{ }^{R}\end{array}$ & $\begin{array}{c}\text { Not } \\
\text { reported } \\
6.5 \\
\end{array}$ & $\begin{array}{c}\text { 3-year risk in IT } \\
\text { prophylaxis vs. nil: } \\
5 \% \text { vs. } 1.8 \%(P=0.083)^{\mathrm{R}} \text {. } \\
\text { IT prophylaxis not } \\
\text { associated with CNS } \\
\text { relapse on MVA } \\
(P \text {-value not reported). }\end{array}$ & 2 \\
\hline $\begin{array}{l}\text { Kanemasa et al. } \\
\text { Ann Hematol } \\
2016^{28}\end{array}$ & 413 & $\begin{array}{c}\text { Retrospective } \\
\text { single center; } \\
\text { 2004-2015 }\end{array}$ & $\begin{array}{c}\text { No age limit } \geq 1 \\
\text { defined; } \\
\text { untreated } \\
\text { de novo DLBCL }\end{array}$ & $\begin{array}{c}\geq 1 \text { cycle R-CHOP } \\
\text { R-CHOP-like } \\
\text { or } \\
(100 \%)\end{array}$ & $\begin{array}{c}\text { Total: } 27 \\
\text { Isolated: } 16 \\
\text { Concurrent: } 11\end{array}$ & $\begin{array}{c}15.0 \% \geq 1 \text { IT } \\
\text { MTX +/-ara-C } \\
\text { prophylaxis }\end{array}$ & 15 months & $\begin{array}{c}\text { 5-vear: } \\
\text { 8.4\% (95\% } \\
\text { Cl: } 5.6-12.4 \%) \\
\end{array}$ & $\begin{array}{l}9 \text { parenchymal; } \\
2 \text { both; } \\
16 \\
\text { leptomeningeal } \\
\mathrm{N}\end{array}$ & $\begin{array}{l}\text { IT prophylaxis no } \\
\text { protective effect } \\
\text { on UVA (HR } 0.85 \text {, range } \\
(0.29-2.45) P=0.76) \text {. } \\
\text { No IPI-adjusted analysis } \\
\text { or MVA performed. }\end{array}$ & 2 \\
\hline $\begin{array}{l}\text { Gleeson et al. } \\
\text { Ann Oncol } \\
2017^{27}\end{array}$ & 984 & $\begin{array}{c}\text { Post hoc } \\
\text { analysis of } \\
\text { R-CHOP-14 us. } \\
21 \text { trial; 2005-20 }\end{array}$ & $\begin{array}{l}\quad \geq 18 \\
\text { years with } \\
\text { untreated } \\
08 \quad \text { bulky } \\
\text { stage I or stage } \\
\text { II-IV DLBCL }\end{array}$ & $\begin{array}{l}\text { R-CHOP-14 } \\
\text { or } 21(100 \%)\end{array}$ & $\begin{array}{c}\text { Total: } 21 \\
\text { Isolated: } 11 \\
\text { Concurrent: } 10 \\
\\
1\end{array}$ & $\begin{array}{c}175(17.8 \%) \\
\text { overall: *163 IT } \\
\text { MTX (16.6\%); } \\
11 \text { unknown; } \\
\text { IT ara-C and MT }\end{array}$ & $\begin{array}{l}8.1 \text { months } \\
\text { (95\% CI: } 1.0-15.1) \\
\text { TX }\end{array}$ & $\begin{array}{c}6.5 \text { year: } \\
1.9 \%\end{array}$ & $\begin{array}{l}17 \text { parenchymal; } \\
4 \text { leptomeningeal }\end{array}$ & $\begin{array}{l}\text { Adjusting for CNS-IPI, } \\
\text { benefit } \\
\text { no demonstrated } \\
\text { (HR=1.12; } 95 \% \mathrm{Cl} \text {, } \\
0.40-3.14 ; \mathrm{p}=0.83)\end{array}$ & 2 \\
\hline $\begin{array}{l}\text { Malecek et al. } \\
\text { Am J Hematol } \\
2017^{26}\end{array}$ & 223 & $\begin{array}{r}\text { Retrospective } \\
\text { multi-center; } \\
\text { 2004-2014 }\end{array}$ & $\begin{array}{l}\text {, } 18 \text { years, } \\
\text { untreated } \\
\text { de novo DLBCL } \\
\text { or transformed } \\
\text { (CLL or FL), } \\
\text { GZ NHL, PMBCL. }\end{array}$ & $\begin{array}{l}\geq 2 \text { cycles } \\
\text { R-DA-EPOCH. } \\
\text { No ASCT } \\
\text { consolidation } \\
\quad(100 \%)\end{array}$ & $\begin{array}{c}\text { Total: } 13 \\
\text { Isolated: } 13 \\
\text { Concurrent: } 0\end{array}$ & $\begin{array}{l}38.6 \%(86 / 223) \\
\text { (IT MTX 83; } \\
\text { IT ara-C 2; } \\
\text { IT MTX and } \\
\text { ara-C 1) }\end{array}$ & $\begin{array}{l}10 \text { months } \\
\text { (range } \\
2.1-27.0 \text { ) }\end{array}$ & $\begin{array}{r}\text { Not reported; } 4 \\
\text { overall rate: } 5.8 \% \\
5 \text { I }\end{array}$ & $\begin{array}{l}4 \text { parenchymal; } \\
\text { 0 } 1 \text { both; } \\
\text { leptomeningeal; } \\
3 \text { unknown } \\
\\
\text { Subgrol } \\
7(5 \%) \\
\text { in r } \\
(P=0.65 \\
\text { MVA }\end{array}$ & $\begin{array}{l}\text { In all patients; } \\
5.8 \% \text { rate of CNS } \\
\text { l; } \text { relapse in both } \\
\text { IT prophylaxis } \\
\text { and no prophylaxis } \\
\text { groups }(P>0.99 \text { ). } \\
\text { pup (n=139) non-HIV DLBCL: } \\
\text { CNS relapse; no difference } \\
\text { risk for prophylaxis vs. nil } \\
\text { 699), no factors significant in } \\
\text { (assuming this included IT } \\
\text { prophylaxis). }\end{array}$ & . \\
\hline $\begin{array}{l}\text { Wudhikarn et al. } \\
\text { Ann Hematol } \\
2017^{75}\end{array}$ & 12034 & $\begin{array}{c}\text { Retrospective } \\
\text { nationwide } \\
\text { multi-center; } \\
\text { 2006-2013 }\end{array}$ & $\begin{array}{c}\geq 15 \text { years } \\
\text { with } \\
\text { untreated } \\
\text { DLBCL; } \geq 1 \text { cycle } \\
\text { of CHOP-like }\end{array}$ & $\begin{array}{c}\text { R-CHOP } \\
\text { or RCHOP-like: } \\
663 \\
\text { CHOP-like: } \\
\quad 1371\end{array}$ & $\begin{array}{c}\text { Total: } 61 \\
\text { Isolated: } 47 \\
\text { Concurrent: } 14\end{array}$ & $\begin{array}{c}10.9 \% \text { IT } \\
\text { prophylaxis. } \\
11.8 \% \text { R. } \\
8 \text { HDMTX or } \\
\text { ara-C overall. }\end{array}$ & $\begin{array}{c}8.4 \text { months } \\
\text { (IQR 5.9-12.2) }\end{array}$ & $\begin{array}{c}\text { 2-year: } \\
2.7 \% \\
(95 \% \text { CI 2.0-3.5\%) } \\
\\
\end{array}$ & $\begin{array}{l}23 \\
\text { parenchymal; } \\
7 \text { both; } \\
25 \\
\text { leptomeningeal; } \\
\text { unknown; } 6 \\
\\
\text { This 1 } \\
(P<0 .\end{array}$ & $\begin{array}{l}\text { IT prophylaxis no } \\
\text { protective effect on } \\
\text { UVA (HR } 3.5, \text { range } \\
1.98-6.06, P<0.001) \\
\text { higher in those } \\
\text { receiving IT } \\
\text { prophylaxis). } \\
\text { remained the case in MVA } \\
0.001, \text { no effect size given). }\end{array}$ & 2 \\
\hline $\begin{array}{l}\text { Klanova et al. } \\
\text { Blood } \\
2019^{24 * * *}\end{array}$ & 1418 & $\begin{array}{l}\text { Post hoc } \\
\text { analysis } \\
\text { of GOYA trial } \\
\text { or }\end{array}$ & $\begin{array}{l}\geq 18 \text { years, } \\
\text { untreated } \\
\text { de novo } \\
\text { DLBCL; IPI } \geq 2 \\
\text { IPI } 1 \text { if } \leq 60 \text { years } \\
\text { or IPI } 0 \text { if bulk }\end{array}$ & $\begin{array}{l}\text { O-CHOP: } 706 \\
\text { R-CHOP: } 712\end{array}$ & $\begin{array}{c}\text { Total: } 38 \\
\text { Isolated: N/R } \\
\text { Concurrent: N/R }\end{array}$ & $\begin{array}{c}9.9 \% \\
\text { (140/1418) IT } \\
\text { prophylaxis } \\
\text { (either MTX, } \\
\text { ara-C or both) }\end{array}$ & $\begin{array}{l}8.5 \text { months } \\
\text { (range 0.9-43.5) }\end{array}$ & 2-year: 2.8\% & $\begin{array}{l}27 \\
\text { parenchymal; } \\
3 \text { both; } \\
\text { leptomeningeal; } \\
1 \text { intraocular; } \\
\text { unknown; } 1 \\
\text { anc } \\
\text { No } \\
\text { IT }\end{array}$ & $\begin{array}{l}\text { 2-year CNS relapse } \\
\text { rate no different } \\
\text { between IT vs. no } \\
\text {; IT prophylaxis: } \\
\quad \text { overall } \\
\quad(2.8 \% \text { vs. } 2.6 \%) \\
\text { d according to CNS-IPI. } \\
0 \text { formal MVA including } \\
\text { prophylaxis performed. }\end{array}$ & 3 \\
\hline
\end{tabular}

*two patients received high dose methotrexate. ${ }^{* *}$ five CNS involvement at diagnosis excluded. R $=$ in RCHOP subgroup. ${ }^{* *}$ studies added after initial and post-systematic review scoping. NCCN: National Comprehensive Cancer Network; CNS: central nervous system; R-CHOP: rituximab, cyclophosphamide, doxorubicin, vincristine, prednisolone; RDA-EPOCH: rituximab plus dose adjusted etoposide, prednisolone, vincristine, cyclophosphamide, doxorubicin; O-CHOP: obinutuzumab, cyclophosphamide, doxorubicin, vincristine, prednisolone DLBCL: diffuse large B-cell lymphoma; NHL: non-Hodgkin lymphoma;ASCT: autologous stem cell transplantation; HGT: high grade transformation;CLL: chronic lymphocytic leukaemia; FL: follicular lymphoma; GZ: gray zone; CR1: first complete remission; PMBCL: primary phoma; ASCT:autologous stem cell transplantation; HGT:high grade transformation; CLL: chronic lymphocytic leukaemia; FL: follicular lymphoma; GZ: gray zone; CRI: first complete remission; PMBCL: primary
mediastinal B-cell lymphoma; IPI: international prognostic index; IT: intrathecal; MTX: methotrexate; HD: high dose; ara-C: cytarabine; HC: hydrocortisone; HR: hazard ratio; CI: confidence interval; UVA: univariable analysis; MVA: multivariable; N/R: not reported; IQR: interquartile range; RR: risk ratio; OS: overall survival; PFS: progression-free survival. 
Table 4. Recommendations for central nervous system prophylaxis within individual studies.

\begin{tabular}{|c|c|c|}
\hline Reference: author, year, journal & $\begin{array}{l}\text { Recommendations for CNS } \\
\text { intrathecal prophylaxis }\end{array}$ & $\begin{array}{l}\text { High risk disease sites or clinical features } \\
\text { for which CNS prophylaxis recommended }\end{array}$ \\
\hline Boehme et al., Blood, $2009^{30}$ & Mandatory for 'high risk' sites & $\begin{array}{l}\text { Bone marrow, testes, upper neck or head including } \\
\text { nasal sinuses, orbital, oral cavity, tongue, and salivary } \\
\text { glands. }\end{array}$ \\
\hline Shimazu et al., Int J Hematol $2009^{31}$ & $\begin{array}{l}\text { Discretion of treating physician, } \\
\text { but recommendations provided }\end{array}$ & Nasal sinuses, testis or vertebra \\
\hline Villa et al., Ann Oncol 200925 & $\begin{array}{l}\text { Discretion of treating physician, } \\
\text { but recommendations provided }\end{array}$ & $\begin{array}{l}\text { Pre-2002: bone marrow or peripheral blood involvement, } \\
\text { epidural, advanced-stage testicular lymphoma, or sinus } \\
\text { involvement. After 2002, only sinus involvement. }\end{array}$ \\
\hline Tai et al., Ann Oncol $2011^{2}$ & Discretion of treating physician. & Not defined \\
\hline Guirguis et al., Br J Haematol $2012^{17}$ & $\begin{array}{l}\text { Per 'high-risk' DLBCL according } \\
\text { to our locally published haematology } \\
\text { site group }\end{array}$ & Unavailable \\
\hline Kumar et al., Cancer, $2012^{29}$ & Discretion of treating physician. & Not defined \\
\hline Song et al., Medicine (Baltimore), $2015^{32}$ & $\begin{array}{l}\text { Discretion of treating physician, } \\
\text { but recommendations provided }\end{array}$ & $\begin{array}{l}\text { Given to patients with high intermediate/high IPI } \\
\text { or involvement of testis, breast, nasal cavity or orbit. }\end{array}$ \\
\hline Tomita et al., Leuk Lymphoma, $2015^{33}$ & $\begin{array}{l}\text { A written strategy prior to the study, } \\
\text { even if it not necessarily followed. }\end{array}$ & $\begin{array}{l}\text { In general, } \geq 1 \text { risk factor: } \mathrm{LDH} \geq 2 \mathrm{ULN} \text {; bulk } \geq 10 \mathrm{~cm} \text {; } \\
\text { ECOG PS 2; or involvement of the bone marrow, skin, } \\
\text { testis, nasal/ paranasal tissue, bone or breast. }\end{array}$ \\
\hline Cai et al., Chin J Cancer, $2016^{34}$ & $\begin{array}{l}\text { Discretion of the local investigator } \\
\text { but recommendations provided }\end{array}$ & $\begin{array}{l}\text { High level of Ki- } 67 \text {; and involvement } \\
\text { of the testis, breast, or kidney. }\end{array}$ \\
\hline Kanemasa et al., Ann Oncol $2016^{28}$ & $\begin{array}{l}\text { Discretion of treating physician, } \\
\text { but recommendations provided }\end{array}$ & Testis, breast, paranasal sinuses, or bone marrow. \\
\hline Gleeson et al., Ann Oncol201727 & $\begin{array}{l}\text { Discretion of the local investigator } \\
\text { but recommendations provided }\end{array}$ & $\begin{array}{l}\text { Bone marrow, peripheral blood, } \\
\text { nasal/paranasal sinuses, orbit and testis. }\end{array}$ \\
\hline Malecek et al., Am J Hematol $2017^{26}$ & Discretion of treating physician. & Not defined \\
\hline Wudhikarn et al., Ann Hematol $2017^{35}$ & Not reported & Not defined \\
\hline Klanova et al., Blood, $2019^{24}$ & Discretion of treating physician. & Not defined \\
\hline
\end{tabular}

CNS: central nervous system; ECOG: Eastern co-operative oncology group; PS: performance status, LDH: lactate dehydrogenase; DLBCL: diffuse large B cell lymphoma.

may not be comparable between studies, with just two making it clear that they treated deaths as a competing risk $^{31,35}$ (Shimazu et al. and Wudhikarn et al.) and none of the studies appearing to consider systemic only relapse as a competing risk, even those that did not include CNS relapse post systemic relapse as an event.

Perhaps the most convincing evidence of the lack of efficacy of IT CNS prophylaxis in the rituximab era comes from the RICOVER-60 trial. $^{30}$ All patients considered high-risk (infiltration of bone marrow and testes or sites in the upper neck or head), should have been treated with IT MTX. There was significant noncompliance to this rule with only $57.1 \%$ receiving CNS prophylaxis. This allowed Boehme and colleagues to perform as subgroup analysis. They found that, in a multivariable Cox model including IPI factors, there was a significant interaction between IT MTX exposure and rituximab exposure $(R R=6.1)$, with risk of CNS relapse significantly reduced with IT MTX in the CHOP group but with no difference seen in the R-CHOP group. The effect of rituximab was significant regardless of IT MTX. This is a non-randomised comparison in a small subset of patients (47-67 per group and only six events in the Rtreated cohort) who were all aged over 60 years and not all had DLBCL. However, it is the only paper to provide any evidence of a differential effect of IT MTX in rituximab-treated versus non-rituximab treated patients, which is not simply based on lower rates of CNS relapse when compared to data from the pre-rituximab era.

Although none of these papers show any evidence of a benefit in giving CNS IT prophylaxis in either univariable analyses or multivariable analyses, they are also all unable to convincingly rule one out due to small numbers of events and the confounding caused by the indications for CNS prophylaxis.

Subsequent to the completion of the systematic review, we have recently published outcomes of 690 elderly patients ( $\geq 70$ years) treated with R-CHOP (full or dose attenuated). ${ }^{38}$ Our results are consistent with those presented within the systematic review but suffer from similar issues of small event number and the risk of confounding factors. We also showed no clear benefit for stand-alone IT prophylaxis although we found that IT prophylaxis was associated with an increased risk of infection-related hospital admission during R-CHOP (odds ratio vs. no prophylaxis) 2.20 (95\% CI: 1.31-3.67; $P=0.01)$.

The only real method to formally answer this question is with a randomised clinical trial of IT CNS prophylaxis vs no IT CNS prophylaxis in patients deemed unsuitable for high dose MTX. Unfortunately, due to the low event 
rate this would need to be a very large study. Even if we assume a relatively high risk patient group (e.g. CNS-IPI 4-6) with a 4-6\% risk of CNS relapse and aim to detect a large effect size (i.e. a halving of this rate), to achieve $80 \%$ power we would require 1,432 (6-3\%), 1,722 (5-2.5\%) or $2,368(4-2 \%)$ patients. Despite the lack of conclusive evidence of its benefit, it may be difficult to persuade many clinicians to randomise patients with multiple baseline risk factors to potentially receive no CNS directed therapy. A trial performed in patients considered unsuitable for high dose methotrexate due to age, renal impairment, performance status or comorbidities would prove particularly challenging to perform.

\section{CASP analysis}

For the 14 studies included within the systematic review, a CASP analysis was performed. Cohort studies were scored as moderate in three studies..$^{24,30,37}$ These included 2 of the 3 post hoc analyses performed from large prospective randomised clinical trials ${ }^{24,30}$ and scored moderate to low in the remaining 11 studies. The key reasons for the low quality rating scores included: a) retrospective, single centre data; b) low event numbers with unadjusted analyses; c) variable indications and IT prophylaxis regimens used; d) variable histologies included.

\section{Strengths and limitations}

No previous systematic review has explored the potential benefit of stand-alone IT prophylaxis in rituximab or obinutuzumab exposed DLBCL patients. To ensure transparency and to facilitate scrutiny of this review, a systematic protocol was registered and published prior to conducting the review, which was undertaken according to best practice and reporting guidelines. Each stage of the review process was independently double-screened, and any discrepancies discussed among the research team until consensus was reached. One limitation of the search strategy was restricting the search to publications in English; however the search expansion strategy ensured a comprehensive and sensitive review. The quality of evidence reviewed was limited by the small number of CNS relapse events in many of the studies. A number of the studies highlighted were initially powered for other means i.e. the primary end point of the specific clinical trial. As such, within trial GOYA and R-CHOP 14 versus 21 populations, for example, there was a heterogenous approach to the use of IT prophylaxis with variable criteria for delivery, dosing schedules and chemotherapy used.

\section{Recommendations}

On the basis of the evidence analysed within this systematic review, there are no convincing published data, adjusted for well described confounding variables, that clearly suggest that stand-alone IT chemotherapy CNS prophylaxis reduces the risk of CNS relapse in patients treated with anthracycline-based front-line immunochemotherapy using an anti-CD20 antibody. It must also be recognised however that no individual study provides strong evidence for lack of benefit of stand-alone IT prophylaxis. The nature of the evidence analysed is limited by the individual study designs, the low event rate, variable prophylaxis protocols used, the retrospective nature of studies, some evidence for lack of compliance and the absence of control groups. Although the quality of evidence precludes firm recommendations, the authors suggest that the available evidence should lead to judicious use of stand-alone IT chemoprophylaxis. Our conclusions relate primarily to patients receiving $\mathrm{R}$ CHOP immunochemotherapy and intentionally do not reference the evidence for high dose anti-metabolites. There was only a single study that studied DA-EPOCH-R and as such conclusions related to IT usage in that setting are more limited. The focus of this systematic review was DLBCL histology, and as such we intentionally have made no conclusions regarding the role of IT prophylaxis in other histologies such as Burkitt lymphoma or indeed specific subgroups of DLBCL such as double hit lymphoma or HIV-associated DLBCL.

\section{Conclusions}

There is no strong evidence to support the use of standalone IT chemotherapy prophylaxis for patients treated with anthracycline-based chemotherapy in the rituximab era. Conversely, the strength of evidence suggesting a genuine lack of evidence is also weak. The majority (70\%) of CNS relapses occurring in anti-CD20 antibody exposed patients treated in our systematic review involved parenchymal tissue. No study within the systematic review reported a toxicity analysis of intrathecal chemotherapy and as such few meaningful conclusions can be made regarding the morbidity of IT prophylaxis from these series. The quality of the data is relatively weak to poor. Although some of the studies included relatively large numbers of patients, the absolute number of CNS relapse events limits the power to perform high quality multivariable analysis or adjusted analysis. As such, we conclude that there is little evidence for the benefit of stand-alone IT CNS prophylaxis in preventing CNS relapse in DLBCL-treated patients using anthracyclinebased immunochemotherapy.

\section{Acknowledgments}

We thank Nia Roberts and Tatjana Petrinic, librarians at Oxford's Bodleian Healthcare Library for their support with the search strategy for this review. Views expressed are those of the authors and not necessarily those of the NHS or the NIHR or the United Kingdom's Department of Health.

\section{Funding}

GPC is supported by the NIHR Biomedical Research Centre, based at Oxford University Hospitals Trust, Oxford. The views expressed are those of the author(s) and not necessarily those of the NHS, Oxford University Hospitals NHS Foundation Trust, the NIHR Biomedical Research Centre or the Department of Health. 


\section{References}

1. El-Galaly TC, Villa D, Michaelsen TY, et al. The number of extranodal sites assessed by PET/CT scan is a powerful predictor of CNS relapse for patients with diffuse large B-cell lymphoma: An international multicenter study of 1532 patients treated with chemoimmunotherapy. Eur J Cancer. 2017; 75:195-203.

2. Tai WM, Chung J, Tang PL, et al. Central nervous system (CNS) relapse in diffuse large B cell lymphoma (DLBCL): Pre- and post-rituximab. Ann Hematol. 2011; 90(7):809-818.

3. Cabannes-Hamy A, Peyrade F, Jardin F, et al. Central nervous system relapse in patients over 80 years with diffuse large Bcell lymphoma: an analysis of two LYSA studies. Cancer Med. 2018;7(3):539-548.

4. Schmitz N, Zeynalova S, Nickelsen M, et al. CNS International Prognostic Index : A risk model for CNS relapse in patients with diffuse large B-cell lymphoma treated with R-CHOP. J Clin Oncol. 2016;34(26):31503156.

5. Ghose A, Elias HK, Guha G, Yellu M, Kundu R, Latif T. Influence of rituximab on central nervous system relapse in diffuse large B-cell lymphoma and role of prophylaxis. A systematic review of prospective studies. Clin Lymphoma, Myeloma Leuk. 2015;15(8):451-457.

6. Boehme V, Zeynalova S, Kloess M, et al. Incidence and risk factors of central nervous system recurrence in aggressive lymphoma - A survey of 1693 patients treated in protocols of the German High-Grade Non-Hodgkin's Lymphoma Study Group (DSHNHL). Ann Oncol. 2007;18(1):149157

7. Abramson JS, Hellmann M, Barnes JA, et al. Intravenous methotrexate as central nervous system (CNS) prophylaxis is associated with a low risk of CNS recurrence in highrisk patients with diffuse large B-cell lymphoma. Cancer. 2010;116(18):4283-4290

8. Ferreri AJM, Bruno-Ventre M, Donadoni G, et al. Risk-tailored CNS prophylaxis in a mono-institutional series of 200 patients with diffuse large B-cell lymphoma treated in the rituximab era. Br J Haematol. 2015; 168 (5):654-662

9. Cheah CY, Herbert KE, O'Rourke K, et al. A multicentre retrospective comparison of central nervous system prophylaxis strategies among patients with high-risk diffuse large B-cell lymphoma. Br J Cancer. 2014; 111(6):1072-1079.

10. Mcmillan A, Ardeshna KM, Cwynarski K, Lyttelton M, Mckay P, Montoto S. Guideline on the prevention of secondary central nervous system lymphoma: British Committee for Standards in Haematology. Br J Haematol. 2013;163(2):168-181.

11. Dunleavy K, Pittaluga S, Shovlin M, et al. Low-intensity therapy in adults with Burkitt's lymphoma. N Engl J Med. 2013;369(20):1915-1925.

12. Pui C-H, Campana D, Pei D, et al. Treating childhood acute lymphoblastic leukemia without cranial irradiation. N Engl J Med. 2009;360 (26):2730-2741

13. Blasberg RG, Patlak C, Fenstermacher JD. Intrathecal chemotherapy: brain tissue profiles after ventriculocisternal perfusion. I
Pharmacol Exp Ther. 1975;195(1):73-83.

14. De la Riva P, Andres-Marín N, GonzaloYubero N, et al. Headache and other complications following intrathecal chemotherapy administration. Cephalalgia. 2016; 37(11):1109-1110.

15. Coiffier B, Lepage E, Briere J, et al. CHOP chemotherapy plus rituximab compared with $\mathrm{CHOP}$ alone in elderly patients with diffuse large-B-cell lymphoma. 2002; 346(4):235-242

16. Zhang J, Chen B, Xu X. Impact of rituximab on incidence of and risk factors for central nervous system relapse in patients with diffuse large B-cell lymphoma: A systematic review and meta-Analysis. Leuk Lymphoma. 2014;55(3):509-514.

17. Guirguis HR, Cheung MC, Mahrous M, et al. Impact of central nervous system (CNS) prophylaxis on the incidence and risk factors for CNS relapse in patients with diffuse large B-cell lymphoma treated in the rituximab era: A single centre experience and review of the literature. Br J Haematol. 2012:159(1):39-49

18. Mitrovic Z, Bast M, Bierman PJ, et al. The addition of rituximab reduces the incidence of secondary central nervous system involvement in patients with diffuse large B-cell lymphoma. Br J Haematol 2012;157(3):401-403

19. Arkenau HT, Chong G, Cunningham D, et al. The role of intrathecal chemotherapy prophylaxis in patients with diffuse large Bcell lymphoma. Ann Oncol. 2007; 18(3):541-545.

20. Tomita N, Kodama F, Kanamori H, Motomura S, Ishigatsubo Y. Prophylactic intrathecal methotrexate and hydrocortisone reduces central nervous system recurrence and improves survival in aggressive non-Hodgkin lymphoma. Cancer. 2002; 95(3):576-580.

21. Grant MJ, Booth A. A typology of reviews: An analysis of 14 review types and associated methodologies. Health Info Libr ]. 2009;26(2):91-108

22. Moher D, Shamseer L, Clarke M, et al Preferred reporting items for systematic review and meta-analysis protocols (PRIS MA-P) 2015 statement. Syst Rev. 2016;4:1.

23. Avilés A, Jesús Nambo M, Neri N. Central nervous system prophylaxis in patients with aggressive diffuse large $B$ cell lymphoma: An analysis of 3,258 patients in a single center. Med Oncol. 2013;30(2):520526.

24. Klanova M, Sehn LH, Bence-Bruckler I, et al. Integration of $\mathrm{COO}$ into the clinical CNS International Prognostic Index could improve CNS relapse prediction in DLBCL. Blood. 2019:133(9):919-926.

25. Villa D, Connors JM, Shenkier TN, Gascoyne RD, Sehn LH, Savage KJ. Incidence and risk factors for central nervous system relapse in patients with diffuse large B-cell lymphoma: The impact of the addition of rituximab to $\mathrm{CHOP}$ chemotherapy. Ann Oncol. 2009;21(5):1046-1052

26. Malecek MK, Petrich AM, Rozell S, et al. Frequency, risk factors, and outcomes of central nervous system relapse in lymphoma patients treated with dose-adjusted EPOCH plus rituximab. Am J Hematol. 2017;92(11):1156-1162.

27. Gleeson M, Counsell N, Cunningham D, et al. Central nervous system relapse of diffuse large B-cell lymphoma in the rituximab era: Results of the UK NCRI RCHOP-14 versus 21 trial. Ann Oncol. 2017;28(10):2511-2516

28. Kanemasa Y, Shimoyama T, Sasaki Y, et al Central nervous system relapse in patients with diffuse large B cell lymphoma: analysis of the risk factors and proposal of a new prognostic model. Ann Hematol. 2016; 95(10):1661-1669.

29. Kumar A, Vanderplas A, Lacasce AS, et al Lack of benefit of central nervous system prophylaxis for diffuse large B-cell lymphoma in the rituximab era: Findings from a large national database. Cancer. 2012;118(11):2944-2951.

30. Boehme V, Schmitz N, Zeynalova S Loeffler M. Pfreundschuh M. CNS events in elderly patients with aggressive lymphoma treated with modern chemotherapy (CHOP-14) with or without rituximab: An analysis of patients treated in the RICOVER-60 trial of the German High-Grade Non-Hodgkin Lymphoma Study Group (DSHNHL). Blood. 2009;113(17):38963902.

31. Shimazu Y, Notohara K, Ueda Y. Diffuse large B-cell lymphoma with central nervous system relapse: Prognosis and risk factors according to retrospective analysis from single-center experience. Int J Hematol. 2009;89(5):577-583

32. Song YS, Lee WW, Lee JS, Kim SE. Prediction of central nervous system relapse of diffuse large B-cell lymphoma using pretherapeutic [18F]2-fluoro-2deoxyglucose (FDG) positron emission tomography/computed tomography. Medicine (Baltimore). 2015;94(44):e1978.

33. Tomita N, Takasaki H, Ishiyama Y, et al Intrathecal methotrexate prophylaxis and central nervous system relapse in patients with diffuse large B-cell lymphoma following rituximab plus cyclophosphamide, doxorubicin, vincristine and prednisone. Leuk Lymphoma. 2015;56(3):725-729.

34. Cai QQ, Hu LY, Geng QR, et al. New risk factors and new tendency for central nervous system relapse in patients with diffuse large B-cell lymphoma: a retrospective study. Chin J Cancer. 2016;35(1):87.

35. Wudhikarn K, Bunworasate U, Julamanee J, et al. Secondary central nervous system relapse in diffuse large B cell lymphoma in a resource limited country: result from the Thailand nationwide multi-institutional registry. Ann Hematol. 2017;96(1):57-64.

36. Peduzzi P, Concato I, Feinstein AR, Holford TR. Importance of events per independent variable in proportional hazards regression analysis II. Accuracy and precision of regression estimates. J Clin Epidemiol. 1995;48(12):1503-1510.

37. Tomita N, Yokoyama M, Yamamoto W, et al. Central nervous system event in patients with diffuse large B-cell lymphoma in the rituximab era. Cancer Sci. 2012·103(2):245-251.

38. Eyre TA, Kirkwood AA, Wolf J, et al. Standalone intrathecal central nervous system (CNS) prophylaxis provide unclear benefit in reducing CNS relapse risk in elderly DLBCL patients treated with R-CHOP and is associated increased infection-related toxicity. Br J Haematol. 2019;187(2):185194. 